\title{
Effect of Glucamylase on Tissue Glycogen and Tissue Glucamylase in the Rat
}

\author{
By W. F. J. CUTHBERTSON, I. D. FLEMING AND M. S. RICE \\ Glaxo Research Ltd., Greenford, Middlesex
}

(Received 2 November 1966)

\begin{abstract}
1. A fungal glucamylase ( $\alpha$-1,4-glucan glucohydrolase, EC 3.2.1.3) from Aspergillus niger depresses liver glycogen stores after intraperitoneal injection into the rat. The injected enzyme rapidly disappears (within about $8 \mathrm{hr}$.) from the serum; less than $1 \%$ is excreted in the urine, but it is rapidly taken up in the liver, spleen, kidney, cardiac and skeletal muscle. Elevated glucamylase concentrations could be demonstrated in liver and spleen tissues for 1-4 days after injection, but in kidney, cardiac and skeletal muscle elevated glucamylase concentrations could be shown only for periods of less than $24 \mathrm{hr}$. after injection of the enzyme.
\end{abstract}

Injected enzymes can act on substrates present in the blood stream or tissue fluids, but would not normally be expected to act on substances within the cells; it is generally believed that large molecules, such as those of an enzyme, cannot rapidly diffuse across a cell membrane. There is, however, evidence that certain enzymes, notably ribonuclease or deoxyribonuclease, applied outside the cell can degrade substrates within the cell (Brachet, 1955, 1956; Pileri, Ledoux \& Vanderhaeghe, 1959; De Lamirande, 1961) and we have shown in a preliminary communication (Cuthbertson \& Fleming, 1964) that three fungal glucamylases $(\alpha-1,4$-glucan hydrolase, EC 3.2.1.3) are capable of depressing tissue glycogen concentrations after intraperitoneal administration to the rat. Jacques \& Bruns (1965) have shown that another carbohydrase, invertase, can be taken up by certain organs after intraperitoneal injection and that the presence of the enzyme within the cell can be demonstrated for a considerable time, and Hiatt (1965) has shown that the injection of pig $\alpha$-amylase increases liver $\alpha$-amylase and blood sugar concentrations and depresses the glycogen content of the liver in both dog and pig.

The investigations described in this paper extend our preliminary observations (Cuthbertson \& Fleming, 1964) on the breakdown of tissue glycogen by injected glucamylase and also determine the distribution of the enzyme within the tissues and its rate of disappearance from them.

\section{MATERIALS AND METHODS}

Rats. Except when otherwise noted, male weanling WAG rats were used (about $3-4$ weeks old and weighing about $50 \mathrm{~g}$.).
Aspergillus niger glucamylase. This preparation (Abdullah, Fleming, Taylor \& Whelan, 1963) was used in all tests unless otherwise indicated. The sample displayed an activity of 18500 units/g. and was administered in $0.9 \% \mathrm{NaCl}$ sterilized by filtration through a sintered-glass filter at concentrations of 460 or 1150 units $/ \mathrm{ml}$. as noted in the text.

Rhizopus delemar glucamylase. A solution of Glutase (Hankyo Kyoei Bussau Co. Ltd., Osaka, Japan) was prepared in $0.9 \% \mathrm{NaCl}$ at 230 units $/ \mathrm{ml}$. and sterilized by filtration through a sintered-glass filter.

Aspergillus phoenicis glucamylase. This preparation (Staley Manufacturing Co. Inc., Decatur, Ill., U.S.A.) was too toxic for injection at the dosages required; it was therefore dialysed against $0.9 \% \mathrm{NaCl}$ to decrease its toxicity, diluted with $0.9 \% \mathrm{NaCl}$ to 230 units $/ \mathrm{ml}$. and then sterilized by filtration through a sintered-glass filter.

Sodium caseinate suspension. Sodium caseinate (5g.) (New Zealand Dairy Board, London, S.E. 1) was dispersed in $100 \mathrm{ml}$. of $0.9 \% \mathrm{NaCl}$ and sterilized by autoclaving ( $30 \mathrm{~min}$. at $0.75 \mathrm{~kg} . / \mathrm{cm}^{2}$ steam pressure).

Glucose oxidase. This was obtained from Sigma Chemical Co., St Louis, Mo., U.S.A.

Horse-radish peroxidase. This was obtained from Sigma Chemical Co.

Soluble starch. This was obtained from Hopkin and Williams Ltd., Chadwell Heath, Essex, A.R. grade.

o-Dianisidine hydrochloride. Prepared from an ethanolic solution of the free base by precipitation with conc. HCl to yield a precipitate, which was filtered, washed with ether and dried under reduced pressure.

Benzidine dihydrochloride. Prepared by the same procedure as used for 0 -dianisidine hydrochloride.

Tissue preparation. The animals were killed by a blow on the head. Tissues (liver, heart, kidney, spleen and skeletal muscle) were rapidly removed, blotted free of blood and fluids, weighed, placed in small test tubes, rapidly frozen in acetone-solid $\mathrm{CO}_{2}$ and kept in the deep-freeze until required.

Spleen, kidney, heart and muscle (about $200 \mathrm{mg}$.) were 
chopped with scissors and then homogenized with $5 \mathrm{ml}$. of ice-cold $0.05 \mathrm{M}$-acetate buffer, pH5.6, in a Potter \& Elvehjem (1936) homogenizer. Livers were similarly dispersed in $10 \mathrm{ml}$. of acetate buffer, $\mathrm{pH} 5 \cdot 6$. All homogenates were clarified by centrifugation (10min. at $2000 \mathrm{~g}$ ) before being assayed for glucamylase activity.

Serum samples. Blood was obtained either from the heart or from animals killed by decapitation. After the blood had clotted, it was centrifuged and kept in the refrigerator (for not more than a few hours) until assayed.

Blood samples. Samples for blood sugar tests were taken from the thoracic cavity immediately after death by puncture of the major thoracic blood vessels.

Determination of glucamylase activity. A $0.1 \mathrm{ml}$. portion of a suitably diluted enzyme preparation was incubated with $0.1 \mathrm{ml}$. of $1.0 \%(w / w)$ soluble starch solution, in $0.05 \mathrm{M}$-acetate buffer, pH4.6, at $37^{\circ}$ for $15 \mathrm{~min}$. The mixture was then heated, in a boiling-water bath, for $2 \mathrm{~min}$. to stop the reaction, and the volume of the mixture was adjusted after cooling to $1 \cdot 0 \mathrm{ml}$. The glucose liberated in the digest was then determined by the glucose-oxidase procedure of Fleming \& Pegler (1963). One unit of activity is the amount that releases $1 \mu$ mole of glucose/min. under the conditions described.

Determination of blood in tissues. Total tissue haem was determined in $0.1 \mathrm{ml}$. samples of the tissue homogenates after centrifugation, by a modification of the method of Bing \& Baker (1931) described by Dacie \& Lewis (1963). From the results obtained, the blood content was calculated, assuming that blood contains $14 \mathrm{~g}$. of haemoglobin/ $100 \mathrm{ml}$. and that all the tissue haem originated from residual blood within the tissues.

Determination of tissue glycogen. Glycogen was extracted from the tissue [a whole spleen, liver, heart or kidney was employed for each assay, or a portion of $100-200 \mathrm{mg}$. of skeletal (gastrocnemius) muscle] by the method of Good, Kramer \& Somogyi (1933) and then measured by the total carbohydrate method of Trevelyan \& Harrison (1952).

Determination of blood sugar. The method of Hoffman (1937) adapted for use on the Technicon (1963) AutoAnalyser was used to determine blood glucose.

\section{EXPERIMENTAL AND RESULTS}

All rats were housed individually in metal cages without access to food, but with water freely available, except when otherwise noted.
Enzyme solutions were made with aseptic precautions, in sterile $0.9 \%$ sodium chloride (saline). All injections were made by the intraperitoneal route in volumes of $0.05-0.6 \mathrm{ml}$.

Effect of glucamylase injection on liver glycogen of rats dosed with glucose. Twenty-nine rats (mean weight $38 \mathrm{~g}$.) were given $1 \mathrm{ml}$. of aq. $50 \%(\mathrm{w} / \mathrm{v})$ glucose solution by stomach tube, and allocated at random to four groups of six and one of five animals. One hour after administration of the glucose, the group of five rats (group 3, Table 1) was killed and 12 rats in two of the remaining groups (groups 1 and 2, Table 1) were injected with 230 units of glucamylase in $0.2 \mathrm{ml}$. of saline; the remaining 12 animals (groups 4 and 5) each received an injection of $0.2 \mathrm{ml}$. of sterile saline only. At $2 \mathrm{hr}$. after administration of the enzyme, one group of six rats that had received enzyme (group 1), and another group given saline (group 4), were killed. At $4 \mathrm{hr}$. after administration of the enzyme all surviving rats (groups 2 and 5) were killed. Immediately after death, the liver was removed from each animal and digested with potassium hydroxide for separation and determination of the liver glycogen. The mean liver glycogen concentrations observed in each group, with the standard errors of the means, are noted in Table 1.

Effect of glucamylase on liver glycogen of normally fed rats. A similar test was carried out, but in this instance the rats were given normal stock diet until immediately before the test and were not given any glucose. During the test, water was available but no food. Fourteen rats (mean weight $75 \mathrm{~g}$.) were randomly allocated to two groups, each of three rats, and four groups, each of two animals. All animals in half the groups were injected with $0.2 \mathrm{ml}$. of saline and the others with $0.2 \mathrm{ml}$. of saline containing 230 units of glucamylase. The groups were killed at 1, 2 and $4 \mathrm{hr}$. after injection, as noted in Table 2, and the livers were at once removed for liver glycogen assays, the results of which are shown in Table 2.

Effect of sodium caseinate on liver glycogen concentrations. Twelve rats (mean weight $33 \mathrm{~g}$.) were

\section{Table 1. Effect of glucamylase on mean liver glycogen of rats given glucose before the enzyme}

Groups of rats (mean wt. $38 \mathrm{~g}$.) were given $500 \mathrm{mg}$. of glucose $2 \mathrm{hr}$. before the enzyme. Further experimental details are given in the text. Results are given as means \pm S.E.M.

$\begin{array}{cccc}\begin{array}{c}\text { Group no. } \\ \text { (and size) }\end{array} & \begin{array}{c}\text { Glucamylase } \\ \text { injected } \\ \text { (units) }\end{array} & \begin{array}{c}\text { Time killed } \\ \text { after injection } \\ \text { (hr.) }\end{array} & \begin{array}{c}\text { Liver glycogen } \\ \text { (mg./g. of wet } \\ \text { tissue) }\end{array} \\ 1(6) & 230 & 2 & 37 \cdot 0 \pm 3 \cdot 5 \\ 2(6) & 230 & 4 & 38 \cdot 7 \pm 8 \cdot 6 \\ 3(5) & \text { Nil } & 0 & 67 \cdot 5 \pm 5 \cdot 0 \\ 4(6) & \text { Nil } & 2 & 75 \cdot 4 \pm 11 \cdot 8 \\ 5(6) & \text { Nil } & 4 & 60 \cdot 3 \pm 5 \cdot 6\end{array}$


taken from cages in which both food and water had been available and were allocated at random to one or other of three groups, each of four animals, which were then given, by intraperitoneal injection (per $100 \mathrm{~g}$. body wt.), $0.5 \mathrm{ml}$. of $0.9 \%$ saline, $0.5 \mathrm{ml}$. of glucamylase (460 units $/ \mathrm{ml}$.) or $0.5 \mathrm{ml}$. of $5 \%$ sodium caseinate. At $3 \mathrm{hr}$. after injection all the animals were killed for liver glycogen determinations. The mean liver glycogen concentrations were $57 \pm 12 \cdot 6,29 \pm 2 \cdot 2$ and $47 \pm 5 \cdot 3 \mathrm{mg} \cdot / \mathrm{g}$. of fresh liver in the rats given saline, glucamylase and sodium caseinate respectively.

Effect of glucamylase on liver and heart glycogen concentrations. Twelve rats (mean weight $40 \mathrm{~g}$.) were taken from cages in which food and water had both been available and were then allocated at random to four groups, each of three animals, which were then housed with access to water but no food. The rats were then injected with enzyme in $0.9 \%$ saline solution to provide $0,115,230$ and 460 units of glucamylase $/ 100 \mathrm{~g}$. body wt. Three hours after injection the animals were killed; their livers and hearts were removed immediately after death and assayed for glycogen content. The results observed are summarized in Table 3 . The hearts were dissected free of fat, major vessels and auricles, so that only the cardiac ventricular muscle was assayed for glycogen content.

A further group of 12 rats (mean weight $45 \mathrm{~g}$.) was used in a test identical with the last, except that these animals were injected with doses of 0 , 29,58 or 115 units of glucamylase $/ 100 \mathrm{~g}$. body wt. The liver and heart glycogen contents noted in these animals are shown in Table 4.

Table 2. Effect of glucamylase on liver glycogen of rats not given glucose before the test

Mean wt. of the rats was $75 \mathrm{~g}$. Further experimental details are given in the text.

$\begin{array}{cccc}\begin{array}{c}\text { Group no. } \\ \text { (and size) }\end{array} & \begin{array}{c}\text { Glucamylase } \\ \text { injected } \\ \text { (units) }\end{array} & \begin{array}{c}\text { Time killed } \\ \text { after injection } \\ \text { (hr.) }\end{array} & \begin{array}{c}\text { Mean liver } \\ \text { glycogen } \\ \text { (mg./g.) }\end{array} \\ \text { 1(3) } & 230 & 1 & 11 \cdot 1 \\ 2(2) & 230 & 2 & 6 \cdot 2 \\ 3(2) & 230 & 4 & 0 \cdot 3 \\ 4(3) & \text { Nil } & 1 & 29 \cdot 1 \\ 5(2) & \text { Nil } & 2 & 20 \cdot 9 \\ 6(2) & \text { Nil } & 4 & 2 \cdot 8\end{array}$

Table 3. Effect of various doses of glucamylase on mean liver and cardiac ventricle glycogen of rats

Each group contained three rats and these were killed $3 \mathrm{hr}$. after administration of the enzyme. Further experimental details are given in the text. Results are given as means + S.E.M.

\begin{tabular}{|c|c|c|c|}
\hline Group & $\begin{array}{l}\text { Glucamylase } \\
\text { injected (units/ } \\
\text { l00g. body wt.) }\end{array}$ & $\begin{array}{l}\text { Liver glycogen } \\
\text { (mg./g. of tissue) }\end{array}$ & $\begin{array}{l}\text { Heart glycogen } \\
\text { (mg./g. of tissue) }\end{array}$ \\
\hline $\begin{array}{l}1 \\
2 \\
3 \\
4\end{array}$ & $\begin{array}{r}0 \\
115 \\
230 \\
460\end{array}$ & $\begin{array}{c}55 \pm 11 \cdot 7 \\
36 \cdot 9 \pm 7 \cdot 5 \\
24 \cdot 3 \pm 4 \cdot 1 \\
29 \cdot 8 \pm 5 \cdot 8\end{array}$ & $\begin{array}{l}3 \cdot 23 \pm 0 \cdot 14 \\
3 \cdot 11 \pm 0 \cdot 09 \\
2 \cdot 85 \pm 0 \cdot 71 \\
3 \cdot 27 \pm 1 \cdot 14\end{array}$ \\
\hline
\end{tabular}

Table 4. Effect of various doses of glucamylase on mean liver and cardiac glycogen contents of rats

Each group contained three rats and these were killed $3 \mathrm{hr}$. after administration of the enzyme. Further details are given in the text. Results are given as means \pm S.E.M.

$\begin{array}{cccc}\text { Glucamylase } & \text { Cardiac ventricle } \\ \text { injected } & \text { Liver glycogen } & \text { glycogen } \\ \text { Group } & \text { (units/100g. body wt.) } & \text { (mg./g. of tissue) } & \text { (mg./g. of tissue) } \\ 1 & 0 & 45 \cdot 2 \pm 1 \cdot 7 & 3 \cdot 52 \pm 0 \cdot 14 \\ 2 & 29 & 27 \cdot 0 \pm 5 \cdot 5 & 4 \cdot 26 \pm 0 \cdot 1 \\ 3 & 58 & 35 \cdot 3 \pm 2 \cdot 7 & 4 \cdot 19 \pm 0 \cdot 7 \\ 4 & 115 & 25 \cdot 1 \pm 2 \cdot 0 & 4 \cdot 24 \pm 1 \cdot 1\end{array}$


Effect of different doses of glucamylase on liver and skeletal muscle glycogen of normally fed rats. Twentyfour rats (mean weight $55 \mathrm{~g}$.), which had previously had free access to food, were allocated at random to six groups each of four animals and placed in cages with water but without food. Immediately after allocation, the animals were injected with $0,29,58,115$ and 230 units of glucamylase $/ 100 \mathrm{~g}$. body wt. Three hours later the animals were killed and the livers removed, together with samples of skeletal muscle (about $200 \mathrm{mg}$.), and both tissues were blotted dry, weighed and assayed for liver glycogen. The results are presented in Table 5.

Effect of different doses of glucamylase on liver, heart and skeletal muscle glycogen of rats given glucose. A further test was carried out under the same conditions as the last, but now after the animals (mean weight 59g.) had been allocated to groups and placed in cages without food, they were all given $1 \mathrm{ml}$. of aq. $50 \%$ glucose. One hour after administration of the glucose, the rats were injected with $0,29,58,115,230$ and 460 units of glucamylase/ $100 \mathrm{~g}$. body wt. and killed $3 \mathrm{hr}$. after administration of the enzyme. The livers, hearts and skeletal muscle (about $200 \mathrm{mg}$.) were removed. The organs were dissected free of other tissues, blotted dry and assayed for glycogen content. The results are shown in Table 6.

Effect of Rhizopus delemar and Aspergillus phoenicis glucamylase on rat-liver glycogen. These tests were carried out with the glucamylase preparation from Rhizopus delemar and the dialysed preparation from Aspergillus phoenicis.

Three tests were carried out in which liver glycogen concentrations were determined in the injected rats and their appropriate saline-injected controls $3 \mathrm{hr}$. after injection of the enzyme preparation. Both enzymes were given at the dose 230 units $/ 100 \mathrm{~g}$. body wt. The results of these tests are presented in Table 7.

Effect of glucamylase injection on blood sugar. Eighteen rats, weighing about $200 \mathrm{~g}$. each, were divided into three groups, each of six animals. One group was killed and the blood sugar was determined in each rat; in this group the mean blood sugar was found to be $124 \mathrm{mg} . / 100 \mathrm{ml}$. (s.E.M. $\pm 3 \cdot 92$ ). The six rats in one of the remaining groups were injected with 280 units of glucamylase/ $100 \mathrm{~g}$. body wt., and the remaining animals were injected with saline, $0 \cdot 2 \mathrm{ml} . / 100 \mathrm{~g}$. body wt. After injection, the animals were kept without food but with free access to water. Three hours after injection, the injected animals were killed, and

Table 5. Effect of various doses of glucamylase on mean liver and muscle glycogen content of rats

Each group contained four rats and these were killed $3 \mathrm{hr}$. after administration of the enzyme. Further experimental details are given in the text. Results are given as means \pm s.E.M.

$\begin{array}{cccc}\text { Glucamylase } & \text { Liver glycogen } & \begin{array}{c}\text { Skeletal muscle } \\ \text { glycogen }\end{array} \\ \text { Group } & \text { injected (units/ } & \begin{array}{c}\text { lo0g. body wt.) } \\ \text { (mg./g. of tissue) }\end{array} & \text { (mg./g. of tissue) } \\ 1 & 0 & 30 \cdot 4 \pm 7 \cdot 3 & 2 \cdot 56 \pm 0 \cdot 28 \\ 2 & 29 & 23 \cdot 7 \pm 2 \cdot 0 & 2 \cdot 30 \pm 0 \cdot 29 \\ 3 & 58 & 19 \cdot 2 \pm 1 \cdot 8 & 3 \cdot 10 \pm 0 \cdot 26 \\ 4 & 115 & 17 \cdot 2 \pm 0 \cdot 5 & 3 \cdot 08 \pm 0 \cdot 26 \\ 5 & 230 & 17 \cdot 4 \pm 8 \cdot 9 & 2 \cdot 08 \pm 0 \cdot 63 \\ 6 & 460 & 12 \cdot 0 \pm 6 \cdot 2 & 1 \cdot 74 \pm 0 \cdot 50\end{array}$

Table 6. Effect of various doses of glucamylase on mean liver, cardiac ventricle and skeletal muscle glycogen contents of rats previously given glucose

Each group contained four rats and these were killed $3 \mathrm{hr}$. after administration of the enzyme. Further experimental details are given in the text. Results are given as means \pm s.E.M.

\begin{tabular}{|c|c|c|c|c|}
\hline Group & $\begin{array}{l}\text { Glucamylase } \\
\text { injected (units/ } \\
\text { l00g. body wt.) }\end{array}$ & $\begin{array}{l}\text { Liver glycogen } \\
\text { (mg./g. of tissue) }\end{array}$ & $\begin{array}{l}\text { Cardiac ventricle } \\
\text { glycogen } \\
\text { (mg./g. of tissue) }\end{array}$ & $\begin{array}{c}\text { Skeletal muscle } \\
\text { glycogen } \\
\text { (mg./g. of tissue) }\end{array}$ \\
\hline 1 & 0 & $29 \cdot 9 \pm 7 \cdot 4$ & $3.69 \pm 0.32$ & $4.97 \pm 0.43$ \\
\hline 2 & 29 & $27 \cdot 1 \pm 8 \cdot 5$ & $4.01 \pm 0.41$ & $5.08 \pm 0.77$ \\
\hline 3 & 58 & $24 \cdot 8 \pm 7 \cdot 1$ & $4 \cdot 14 \pm 0 \cdot 30$ & $5.00 \pm 0.52$ \\
\hline 4 & 115 & $17 \cdot 0 \pm 3 \cdot 1$ & $4 \cdot 11 \pm 0.45$ & $5 \cdot 26 \pm 1 \cdot 1$ \\
\hline 5 & 230 & $19 \cdot 1 \pm 8 \cdot 2$ & $3.82 \pm 0.41$ & $4.64 \pm 0.73$ \\
\hline 6 & 460 & $19 \cdot 5 \pm 7 \cdot 3$ & $3 \cdot 76 \pm 0.36$ & $5.23 \pm 1.2$ \\
\hline
\end{tabular}


blood samples were taken from each animal. The mean blood sugar concentrations were found to be $90 \mathrm{mg} . / 100 \mathrm{ml}$. (s.E.M. $\pm 6 \cdot 8$ ) in the saline-injected and $103 \mathrm{mg} . / \mathrm{ml}$. (S.E.M. $\pm 2 \cdot 2$ ) in the glucamylaseinjected groups. In a second similar test, with four rats per group, the mean blood sugar concentrations were found to be $85 \mathrm{mg}$. $/ 100 \mathrm{ml}$. (s.E.M. $\pm 2 \cdot 1$ ) and $93 \mathrm{mg} . / 100 \mathrm{ml}$. (s.E.M. $\pm 9 \cdot 0$ ) after injection of the saline and glucamylase (280 units/100g. body wt.) respectively. In this test the blood sugar concentrations determined in two control animals, at the time of injection of the saline and enzyme solutions, were found to be 110 and $111 \mathrm{mg} . / 100 \mathrm{ml}$.

Urinary excretion of glucamylase. The six rats used in the test were rather larger (70-120g.) than

Table 7. Effect of glucamylase from Aspergillus phoenicis and Rhizopus delemar on liver glycogen content

Further experimental details are given in the text. Each figure represents the observation made on one rat.

$\begin{array}{ccc}\text { Expt. } & \text { Treatment } & \begin{array}{c}\text { Glycogen } \\ \text { (mg./g. of wet } \\ \text { tissue) }\end{array} \\ \text { A } & \text { A. phoenicis enzyme } & \\ & \text { (230 units/100g. body wt.) } & 2 \cdot 8 \\ & & 1 \cdot 2 \\ & & 10 \cdot 1 \\ & & 14 \cdot 2 \\ & \text { Saline } & 15 \cdot 6 \\ & & 39 \cdot 8 \\ & & 3.2 \\ \text { B } \quad \text { A. phoenicis enzyme } & 22 \cdot 3 \\ & \text { (230 units/100g. body wt.) } & 0.7 \\ & & 0 \cdot 8 \\ & \text { Saline } & 21 \cdot 2 \\ & & 14 \cdot 8 \\ \text { C } & \text { R. delemar enzyme } & \\ & \text { (230 units/100g. body wt.) } & 40.9 \\ & & 46.0 \\ & \text { Saline } & 65 \cdot 7 \\ & & 84 \cdot 4\end{array}$

those used for most of the work, to ensure provision of more urine than might otherwise be obtained. The animals were injected with glucamylase as indicated in Table 8 and were housed individually in metabolism cages with food and water available at all times. Each animal was given $2 \mathrm{ml}$. of water, by stomach tube, immediately and also at $24 \mathrm{hr}$. after injection of the enzyme. At the times indicated the voided urine was collected, the urine-collecting apparatus was washed with water, and the combined urine and washings were assayed for glucamylase activity. The results are summarized in Table 8.

Serum glucamylase concentrations after intraperitoneal administration of glucamylase. In a preliminary test, six rats (50-60g.) were divided into two groups of three. The animals of one received saline and of the other. glucamylase injections, 460 units $/ 100 \mathrm{~g}$. body wt. Six hours after the injections, all the rats were killed. The pooled serum obtained from each group was then assayed for glucamylase. The results are shown in Table 9 (A).

In a further test, 21 rats (mean weight 55g.) were allocated to seven groups of three. In six of these groups each rat received 460 units of glucamylase $/ 100 \mathrm{~g}$. body wt.; saline only was administered to the others. These rats were killed at intervals after injection, as shown in Table 9 (B), which also notes the glucamylase concentrations found in the pooled serum from each group. In this test, as in the preliminary experiment, food and water were available to the rats at all times.

Effect of glucamylase injection on glucamylase activity of liver, heart, spleen, kidney and skeletal muscle. Twenty-two female rats (26-38g. body wt.) were divided into two groups, one of ten and the other of 12 rats, each averaging $30-32 \mathrm{~g}$. body wt.

The 12 rats were each injected with $0.25 \mathrm{ml}$. of saline, and the ten remaining animals were each given an injection of 115 units of glucamylase in $0.25 \mathrm{ml}$. of a solution containing 460 units $/ \mathrm{ml}$., i.e. approx. 370 units $/ 100 \mathrm{~g}$. body wt. All animals were then kept in cages with free access to food and

Table 8. Urinary glucamylase activity after injection of glucamylase

Further experimental details are given in the text.

$\begin{array}{cc} & \text { Glucamylase injected } \\ \text { Rat. no. } & \text { (units/100g. body wt.) } \\ \text { 1 } & \text { Nil } \\ 2 & 92 \\ 3 & 92 \\ 4 & 370 \\ \text { 5 } & 370 \\ 6 & 370\end{array}$

Glucamylase activity (units) in urine

\begin{tabular}{lcccccc}
\hline $1 \mathrm{hr}$. & $2 \mathrm{hr}$. & $4 \mathrm{hr}$. & $21 \mathrm{hr}$. & $24 \mathrm{hr}$. & $29 \mathrm{hr}$. & Total \\
0.00 & 0.00 & 0.00 & 0.00 & 0.00 & 0.00 & 0.00 \\
0.07 & 0.03 & 0.78 & 0.17 & 0.00 & 0.17 & 1.2 \\
0.01 & 0.11 & 0.10 & 0.00 & 0.13 & 0.05 & 0.4 \\
0.06 & 0.30 & 0.45 & 0.67 & 0.00 & 0.09 & 1.6 \\
0.00 & 0.42 & 0.39 & 0.17 & 0.17 & 0.14 & 1.3 \\
0.02 & 1.49 & 1.18 & 1.85 & 0.04 & 0.05 & 4.6
\end{tabular}


Table 9. Rat serum glucamylase activity after injection of the enzyme

Groups contained three rats in each. Further experimental details are given in the text. Results are given as means \pm S.E.M.

$\begin{array}{cccc}\text { Expt. } & \begin{array}{c}\text { Time after } \\ \text { injection of } \\ \text { glucamylase (hr.) }\end{array} & \begin{array}{c}\text { Glucamylase } \\ \text { injected (units/ } \\ \text { lo0g. body wt.) }\end{array} & \begin{array}{c}\text { Serum glucamylase } \\ \text { activity } \\ \text { (units/ml.) }\end{array} \\ \text { A } & 0 & 0 & 0 \cdot 7 \pm 0.1 \\ & 6 & 460 & 8 \cdot 5 \pm 0.3 \\ \text { B } & 0 & 0 & 0 \cdot 6 \pm 0.1 \\ & 1 & 460 & 9 \cdot 2 \pm 0.2 \\ & 2 & 460 & 14.4 \pm 0.2 \\ & 4 & 460 & 27.8 \pm 0.5 \\ & 8 & 460 & 0.5 \pm 0.1 \\ & 24 & 460 & 0.5 \pm 0.1\end{array}$

Table 10. Effect of glucamylase injection on glucamylase activity of rat liver, heart, spleen, kidney and skeletal muscle

Each figure is the mean value for two rats; 370 units of enzyme/100g. body wt. were injected.

Glucamylase activity (units/g. of wet tissue)

Time after injection (hr.)

0
2
4
7
24
96

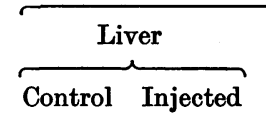

\begin{tabular}{|c|c|}
\hline- & - \\
\hline $5 \cdot 4$ & $7 \cdot 1$ \\
\hline $7 \cdot 5$ & $26 \cdot 4$ \\
\hline 6.7 & 35.4 \\
\hline 6. & 20.8 \\
\hline & $7 \cdot 8$ \\
\hline
\end{tabular}

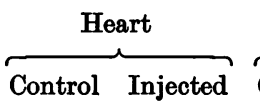

\section{$1 \cdot 30$}

$0 \cdot 22$

0.45

0.55

0.55

0.80

$-\overline{2 \cdot 17}$
$7 \cdot 96$
$4 \cdot 90$
$0 \cdot 55$
$0 \cdot 83$

$\overbrace{\text { Control Injected }}^{\text {Spleen }}$

$\begin{array}{rr}0.6 & - \\ 0.8 & 3.6 \\ 0.9 & 15.7 \\ 0.5 & 10.2 \\ 0.6 & 2.3 \\ 2.0 & 0.4\end{array}$

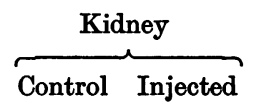

$\overbrace{\text { Control Injected }}^{\text {Muscle }}$

$\begin{array}{ll}2 \cdot 1 & - \\ 1 \cdot 2 & 3 \cdot 1 \\ 1.5 & 5 \cdot 3 \\ 1.9 & 4.3 \\ 1 \cdot 2 & 1 \cdot 1 \\ 1 \cdot 6 & 2.7\end{array}$

$\begin{array}{ll}0.3 & - \\ 0.8 & 1.2 \\ 0.8 & 2.3 \\ 0.9 & 1.7 \\ 0.8 & 1.1 \\ 0.3 & 0.6\end{array}$

Table 11. Glucamylase activity of rat heart, kidney and skeletal muscle assayed in the presence and absence of 0.5 M-erythritol after injection of glucamylase. Approx. 370 units $/ 100 \mathrm{~g}$. body wt. was the amount of enzyme injected

Each figure represents the mean result from three animals. NE, No erythritol added; E, erythritol added.

Glucamylase activity (units/g. of wet tissue)

\begin{tabular}{|c|c|c|c|c|c|c|c|c|c|c|c|c|}
\hline \multirow{3}{*}{$\begin{array}{c}\text { Time after } \\
\text { injection (hr.) }\end{array}$} & \multicolumn{4}{|c|}{ Heart } & \multicolumn{4}{|c|}{ Kidney } & \multicolumn{4}{|c|}{ Muscle } \\
\hline & \multicolumn{2}{|c|}{ Control } & \multicolumn{2}{|c|}{ Injected } & \multicolumn{2}{|c|}{ Control } & \multicolumn{2}{|c|}{ Injected } & \multicolumn{2}{|c|}{ Control } & \multicolumn{2}{|c|}{ Injected } \\
\hline & $\mathrm{NE}$ & $\overrightarrow{\mathbf{E}}$ & NE & $\mathbf{E}$ & NE & $\mathbf{E}$ & $\mathrm{NE}$ & $\mathbf{E}$ & $\mathrm{NE}$ & $\mathbf{E}$ & NE & $\mathrm{N}$ \\
\hline 0 & 0.5 & 0.5 & - & - & $1 \cdot 4$ & 0.6 & - & - & 0.6 & 0.5 & - & - \\
\hline 2 & 0.5 & 0.5 & $1 \cdot 6$ & 1.4 & 1.8 & 0.5 & $2 \cdot 8$ & $1 \cdot 1$ & 0.5 & 0.3 & $1 \cdot 1$ & 0.9 \\
\hline 4 & 0.5 & 0.5 & 1.5 & $1 \cdot 4$ & 1.8 & 0.6 & $2 \cdot 6$ & 0.9 & 0.6 & 0.6 & 1.6 & 1.6 \\
\hline 6 & 0.5 & 0.5 & $2 \cdot 9$ & $2 \cdot 3$ & 1.6 & 0.5 & $4 \cdot 0$ & 1.5 & 0.6 & 1.0 & 1.4 & 1.9 \\
\hline 8 & 0.5 & 0.6 & $2 \cdot 1$ & 1.8 & 1.6 & 0.2 & 3.0 & 0.9 & 1.2 & 1.8 & $1 \cdot 1$ & 1.7 \\
\hline 16 & 0.6 & 0.5 & 0.6 & 0.5 & 1.5 & 0.5 & $2 \cdot 0$ & 0.6 & 0.7 & $1 \cdot 1$ & 1.0 & 1.6 \\
\hline 24 & 0.5 & 0.5 & 0.6 & 0.4 & 1.7 & 0.5 & 1.6 & 0.5 & 0.8 & 1.4 & 0.5 & 1.7 \\
\hline Mean & 0.5 & 0.5 & 1.5 & $1 \cdot 6$ & $1 \cdot 5$ & 0.5 & $2 \cdot 7$ & 0.9 & 0.7 & 0.9 & $1 \cdot 1$ & 1.6 \\
\hline
\end{tabular}

water until killed at the times noted in Table 10. Immediately after death, liver, heart, spleen, kidney and approx. $200 \mathrm{mg}$. of skeletal muscle were removed, blotted, weighed and then frozen in tubes in acetone-solid carbon dioxide. Thereafter all tissues were kept in the deep-freeze until immediately before assay for glucamylase activity. The glucamylase activities of the various organs at 
Table 12. Haem content of rat organs expressed as haemoglobin and total blood content if all haem is present as haemoglobin

Organs were taken from four rats. Each figure represents the mean result from three assays.

$\begin{array}{lccccc} & \text { Liver } & \text { Heart } & \text { Spleen } & \text { Kidney } & \text { Muscle } \\ \begin{array}{l}\text { Haem content as haemoglobin } \\ \text { (mg./g. of wet tissue) }\end{array} & 5 \cdot 2 & 3 \cdot 6 & 30 & 4 \cdot 3 & 0.08 \\ \begin{array}{c}\text { Blood content (\%, if all haem from } \\ \text { blood at } 14 \% \text { haemoglobin) }\end{array} & 3 \cdot 7 & 2 \cdot 6 & 22 & 3 \cdot 3 & 0.06\end{array}$

blood at $14 \%$ haemoglobin)

different times after glucamylase injection are noted in Table 10.

Effect of erythritol on the apparent glucamylase activity of heart, kidney and skeletal muscle of animals with and without administration of glucamylase. Thirty-nine rats (26-38g. body wt.) were used to form two groups, one of 18 and the other of 21, each with a mean body weight of approx. $30 \mathrm{~g}$. The 21 rats were each injected with $0.25 \mathrm{ml}$. of saline, and the rats in the group of 18 each received 115 units of glucamylase in $0.25 \mathrm{ml}$. of saline, i.e. about 370 units of enzyme $/ 100 \mathrm{~g}$. body wt. The animals were further subdivided into sub-groups of three animals each, which were then kept in cages with free access to food and water until killed at the times noted in Table 11. Immediately after death, heart, kidney and skeletal muscle were removed, weighed and treated as in the previous test and then assayed for glucamylase content in both the presence and the absence of $0.5 \mathrm{M}$-erythritol in the enzyme digestion mixture. The results of this experiment are summarized in Table 11.

Total 'blood' content of tissues. Liver, heart, kidney, spleen and skeletal muscle samples from four rats each weighing about $50 \mathrm{~g}$. were homogenized, and then the clear supernatants obtained by centrifugation of these extracts (2000 $\mathrm{g}$ for $10 \mathrm{~min}$.) were assayed for haem pigments by the benzidine method. The mean results from three assays, expressed as haemoglobin on the pooled supernatant of each tissue, are shown in Table 12, which also notes the percentage of blood that the tissues would have contained if all the haem pigments had been present as haemoglobin in blood containing $14 \%$ haemoglobin.

\section{DISCUSSION}

The results given in Tables $1-6$ show that injection of glucamylase from $A$. niger leads to a depression in liver glycogen. With the doses employed, the effect is clearly discernible between 2 and $4 \mathrm{hr}$. after intraperitoneal injection (Tables 1 and 2). Examination of Tables 3-6 shows that $3 \mathrm{hr}$. after administration 29 units of enzyme $/ 100 \mathrm{~g}$. body wt. induced a readily detectable $(P<0.05)$ fall in liver glycogen to about $75 \%$ of the control values; with increasing doses, the liver glycogen concentrations are further depressed to about $50 \%$ of controls after administering 460 units of enzyme/100 g. body wt. The observation that mean liver glycogen concentration after sodium caseinate injections did not differ significantly from those observed after administration of saline $(57 \pm 12 \cdot 6 \mathrm{mg} \cdot / \mathrm{g}$. and $47 \pm 5 \cdot 3 \mathrm{mg}$./g. of wet liver respectively), whereas in the same test glucamylase administration lead to significant depression of liver glycogen $(29 \pm$ $2 \cdot 2 \mathrm{mg}$.g.), supports the belief that the observed effects depend on a specific activity of the glucamylase.

It was thought of interest to determine whether the $A$. niger glucamylase is unique in its ability to depress liver glycogen after intraperitoneal injection or whether other glucamylases could also do so. The results in Table 7 show that the enzyme from $R$. delemar and from $A$. phoenicis are both effective in this respect and so resemble the $A$. niger enzyme and the pig $\alpha$-amylase, studied on the dog and pig by Hiatt (1965).

The liberation of glucose from liver glycogen by glucamylase might be expected partially to prevent the depression of blood sugar that normally occurs on deprivation of food. The results show that the mean blood sugar concentrations of both salineand enzyme-injected animals were significantly $(P<0.05)$ depressed after deprivation of food for $3 \mathrm{hr}$. but that this depression was not as noticeable in glucamylase-treated rats as in the saline-treated controls. Statistical examination of the results from the two tests showed that at this time the mean blood sugar concentration in the glucamylasetreated rats was significantly $(P 0.05)$ higher than in the corresponding saline-treated animals.

Skeletal muscle and cardiac ventricle glycogen contents were also measured in a number of tests, but the results provide no evidence that injection of the enzyme can depress concentrations of cardiac muscle glycogen (Tables 3,4 and 6) or skeletal muscle glycogen (Tables 5 and 6 ).

Studies on the urinary excretion of glucamylase (Table 8) show that little, 1\% or less, of the 
glucamylase is excreted in the urine during the $29 \mathrm{hr}$. after injection and that the maximum excretion rate is observed between 1 and $4 \mathrm{hr}$. after administration. Serum-glucamylase activities after administration of the enzyme are shown in Table 9, from which it can be seen that maximum serum activity is found at about the time (1-4hr.) that the highest rate of urinary excretion was noted and that serum-glucamylase activity had returned to pre-injection values after about $8 \mathrm{hr}$. The observations in Tables 8 and 9 show that the enzyme is rapidly removed from the blood by some mechanism other than elimination in the urine.

Some studies were carried out on the uptake of the fungal glucamylase by a number of tissues (liver, heart, spleen, kidney and muscle) (Table 10), to determine whether the apparent inability of the injected enzyme to affect cardiac and skeletal muscle glycogen could be associated with inability of the enzyme to enter these tissues or to some other effect. Table 10 shows the glucamylase activity of the various organs, as measured by the ability of extracts from the organs to release glucose from starch. The results show that the injection of glucamylase did increase the mean apparent glucamylase content of all these organs two to three times over a period of $2-4 \mathrm{hr}$. after the injection. In absolute terms, the increased glucamylase activity was much greater in the liver than in the other tissues. The rate of disappearance of glucamylase indicated a half-life of between 5 and $20 \mathrm{hr}$. in the different organs. The results are insufficient for precise calculations, but it can be seen that the heart-, kidney-and muscle-glucamylase activities have fallen to control values after $24 \mathrm{hr}$., whereas liver and spleen activities fell to these values within $96 \mathrm{hr}$.

These results differ from those of Jacques \& Bruns (1965), who, working with a different enzyme, yeast invertase, reported that their enzyme, like ours, was taken up with greater avidity by the liver and the spleen than by the kidney, but they noted that the invertase remains active in the liver for weeks, whereas the amount of glucamylase in our tests had fallen to the control values within a few days. Further work is needed to determine whether the enzymes are metabolized in different ways or whether these apparent differences in behaviour may be a result of the different extraction procedures used in the two laboratories.

It is conceivable that the rise in glucamylase activity seen in the organs, especially those in which glycogen mobilization could not be demonstrated, might be due not to the presence of glucamylase within the cells, but rather to the presence of residual blood, containing glucamylase, within the organ. This is unlikely to explain the observations noted with liver, kidney, spleen or heart, because the maximum glucamylase activity of these organs (Tables 10 and 11) does not coincide with maximum serum activity (Table 11); further, glucamylase activity is clearly detectable in these organs for many hours after the serum activity has returned to control values. Apart from this, the 'blood' content of the organs is insufficient to explain the glucamylase activities noted. Table 11 shows the haem content, calculated as haemoglobin, of the various organs and the 'blood' content of these organs, if all this haem is assumed to be in the form of haemoglobin in blood. Calculations from the glucamylase activity of serum (Table 11) show that the glucamylase activity of the blood that may be present in the organs cannot contribute more than a small proportion of the amount noted in the organs after $\mathbf{8 h r}$. Even before this time it is only in muscle and spleen that as much as 25-30\% of the activity could be ascribed to blood. In fact, spleen is known to contain far more red cells than would be expected from its blood content, and muscle contains haem pigments other than haemoglobin from residual blood, so that the presence of blood can only explain the presence of an even smaller proportion of the glucamylase detected.

The observation of Kellerman \& Whelan (1965) that erythritol can inhibit certain glucamylases, but not $A$. niger glucamylase, suggested that assays of tissue glucamylases in the presence and absence of erythritol might, if the tissue enzymes were inhibited, emphasize the contribution made by the fungal enzyme to the total tissue activity. Table 11 summarizes the results obtained in an experiment in which the activity of organ extracts was measured in the presence and absence of erythritol. They show that erythritol has no inhibitory effect on the glucamylase activity of the heart or skeletal muscle, but does strongly inhibit the glucamylase activity of the kidney extract. This observation (Table 11) confirms the inference from the values in Table 10 that the fungal glucamylase is taken up by the kidney and thus differs from the invertase studied by Jacques \& Bruns (1965) in that only 'traces' were taken up by the kidney in their tests.

The failure to demonstrate any effect of injected glucamylase on cardiac or skeletal muscle glycogen could be attributable to the comparatively small amounts of enzyme penetrating these tissues, compared with the quantity entering the liver; further experiments are required to test this possibility or to determine whether cardiac and skeletal muscle glycogen are less readily attacked for some other reason.

The ability of exogenous enzymes to penetrate the cells of certain organs may offer a means of replacing enzymes that may be more or less deficient in subjects suffering from certain metabolic dis- 
eases, such as for instance phenylketonuria and the glycogen-storage diseases. In the glycogen-storage diseases, glycogen accumulates in certain organs of the body (notably the liver, heart and skeletal muscle) because of deficiencies in these organs of one or other of the enzymes essential for the mobilization of glycogen. Administration of the missing enzyme, from the same or another species, would be expected to relieve the glycogen-storage disease and to disperse the glycogen stores from the tissues, if the enzyme could penetrate to and act at the sites normal for the missing enzyme. A. niger glucamylase converts glycogen entirely into glucose by attacking both the $\alpha-1,4-$ and $\alpha-1,6$-glucosidic linkages (Abdullah et al. 1963); this enzyme would therefore be expected to degrade all the different types of glycogen deposited in the various glycogenstorage diseases if it could reach and act at the storage sites within the affected cells. The glucose so formed could then be metabolized and eliminated by pathways other than those leading to glycogen formation. A glucamylase capable of acting at the required site could thus eliminate the excessive glycogen stores characteristic of the glycogenstorage diseases no matter what might be the deficient enzyme. Complete control of the condition, however, could not be expected if the missing enzyme carried out vital functions that could not be fulfilled by glucamylase. Apart from this, there are also other obvious problems, such as those concerned with immunology, that must be solved before exogenous enzymes may be successfully employed in the alleviation of disease.

\section{REFERENCES}

Abdullah, M., Fleming, I. D., Taylor, P. M. \& Whelan, W. J. (1963). Biochem. J. 89, 35P.

Bing, F. C. \& Baker, R. W. (1931). J. biol. Chem. 92, 589.

Brachet, J. (1955). Nature, Lond., 175, 851.

Brachet, J. (1956). Exp. Cell Res. 10, 255.

Cuthbertson, W. F. J. \& Fleming, I. D. (1964). Biochem.J. 92,53 P.

Dacie, J. V. \& Lewis, S. M. (1963). Practical Haematology, p. 380. London: J. and A. Churchill Ltd.

De Lamirande, G. (1961). Nature, Lond., 192, 52.

Fleming, I. D. \& Pegler, H. F. (1963). Analyst, 88, 967.

Good, C. A., Kramer, H. \& Somogyi, M. (1933). J. biol. Chem. 100, 485.

Hiatt, N. (1965). Proc. Soc. exp. Biol., N.Y., 119, 667.

Hoffman, W. S. (1937). J. biol. Chem. 120, 51.

Jacques, P. \& Bruns, G. P. (1965). Abstr. 2nd Meet. Fed. Europ. biochem. Soc., Vienna, A36, p. 26.

Kellerman, V. R. \& Whelan, W. J. (1965). Abstr. 2nd Meet. Fed. Europ. biochem. Soc., Vienna, A25, p. 18.

Pileri, A., Ledoux, L. \& Vanderhaeghe, F. (1959). Exp. Cell Res. 17, 218.

Potter, V. R. \& Elvehjem, C. A. (1936). J. biol. Chem. 114, 495.

Technicon (1963). Technicon Auto-Analyser $N$ Methodology, N-2a. New York: Technicon Instruments Corp.

Trevelyan, W. E. \& Harrison, J. S. (1952). Biochem. J. 50, 298. 